\title{
PERMASALAHAN DAN TANTANGAN DALAM PENINGKATAN SDM DAN PENYEDIAAN KESEMPATAN KERJA BAGI KONTRAKTOR PUTRA DAERAH DI PROPINSI PAPUA BARAT
}

\author{
Hendrik Pristianto, ST., MT. \\ (Peneliti LPJK Propinsi Papua Barat dan Dosen Fakultas Teknik \\ Universitas Muhammadiyah Sorong)
}

A. Pentingnya Peningkatan SDM dan Kesempatan Kerja Bagi Kontraktor Lokal (Kontraktor Putra Daerah) di Propinsi Papua Barat

1. Amanat Undang-Undang Nomor 18 Tahun 1999 pasal 35 tentang Jasa Konstruksi dan Peraturan Pemerintah Nomor 30 Tahun 2000 tentang Penyelenggaraan Pembinaan Jasa Konstruksi, yaitu perlunya upaya pembinaan yang meliputi pengaturan, pemberdayaan, dan pengawasan terhadap masyarakat jasa konstruksi. Hal tersebut dapat dilakukan oleh Pemerintah, Pemerintah Provinsi, Pemerintah Kabupaten/Kota sesuai dengan kewenangan masing - masing.

2. Amanat Undang-Undang Nomor 21 Tahun 2001 tentang Otsus Papua, pasal 62 ayat 2 yaitu : Orang asli Papua berhak memperoleh kesempatan dan diutamakan untuk mendapatkan pekerjaan dalam semua bidang pekerjaan di wilayah Provinsi Papua berdasarkan pendidikan dan keahliannya.

3. Sebagai sarana menjalankan amanat undang undang tentang jasa konstruksi, maka untuk wilayah Papua yang terdiri dari Provinsi Papua dan Provinsi Papua Barat sangat diperlukan adanya Peraturan Daerah Provinsi (PERDASI) mengenai Jasa Konstruksi yang didalamnya mengatur agar layanan jasa konstruksi di daerah ini dapat berlangsung dengan kompetisi yang sehat, dengan mengedepankan kompetensi badan usaha yang ada, khususnya badan usaha jasa konstruksi milik masyarakat papua atau pengusaha orang asli Papua atau diistilahkan dalam paper ini dengan kontraktor lokal/kontraktor Putra Daerah.

4. Yang dibutuhkan oleh masyarakat Papua khususnya kontraktor lokal/kontraktor Putra Daerah di Papua Barat adalah keberpihakan kepada masyarakat papua dengan memberikan kesempatan yang seluas-luasnya secara proporsional untuk menjadi penyedia jasa konstruksi, bukan hanya dengan mempekerjakan pekerja orang asli Papua di wilayah Kabupaten/Kota tempat pelaksanaan pekerjaan konstruksi.

5. Peningkatan jumlah badan usaha (kontraktor) pada era otonomi khusus ini belum disertai dengan peningkatan kualitas dan kinerja SDM-nya, sehingga kualitas/mutu produk, ketepatan waktu pelaksanaan dan efisiensi pemanfaatan sumber daya manusia dan teknologi dalam penyelenggaraan jasa konstruksi belum sebagaimana yang diharapkan. 
B. Perkembangan Kontraktor Lokal (Kontraktor Putra Daerah) di Propinsi Papua Barat

6. Dari hasil penelitian ini didapatkan informasi bahwa :

a. "Jumlah Kontraktor Lokal / Pengusaha Papua di Propinsi Papua Barat Belum Mencapai $50 \%$ dari Total Kontraktor Yang Berdomisili di Wilayah Tersebut".

b. Sebaran

Kontraktor Putra

Daerah

di

Propinsi Papua

Barat berdasarkan

kualifikasi badan

usahanya dapat

dilihat pada

gambar di

samping. Dari

gambar terlihat

bahwa mayoritas

kontraktor lokal

/ kontraktor

Putra Daerah di

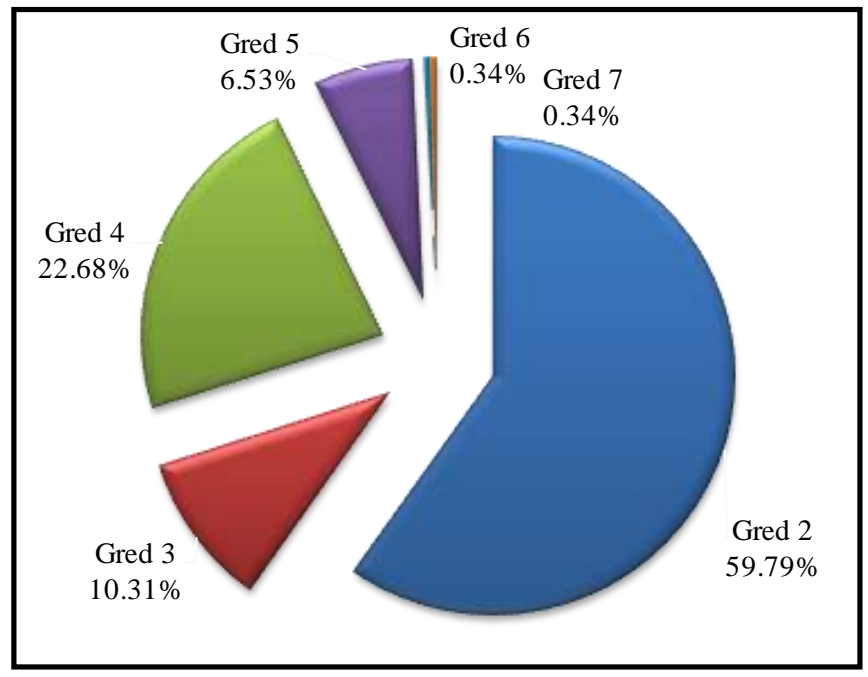

Propinsi Papua Barat berada pada kualifikasi Gred 2, yang berarti pada kategori pengusaha kecil.

c. Karakteristik Sumber Daya Manusia (SDM) yang dimiliki oleh kontraktor lokal / kontraktor Putra Daerah di Propinsi Papua Barat.

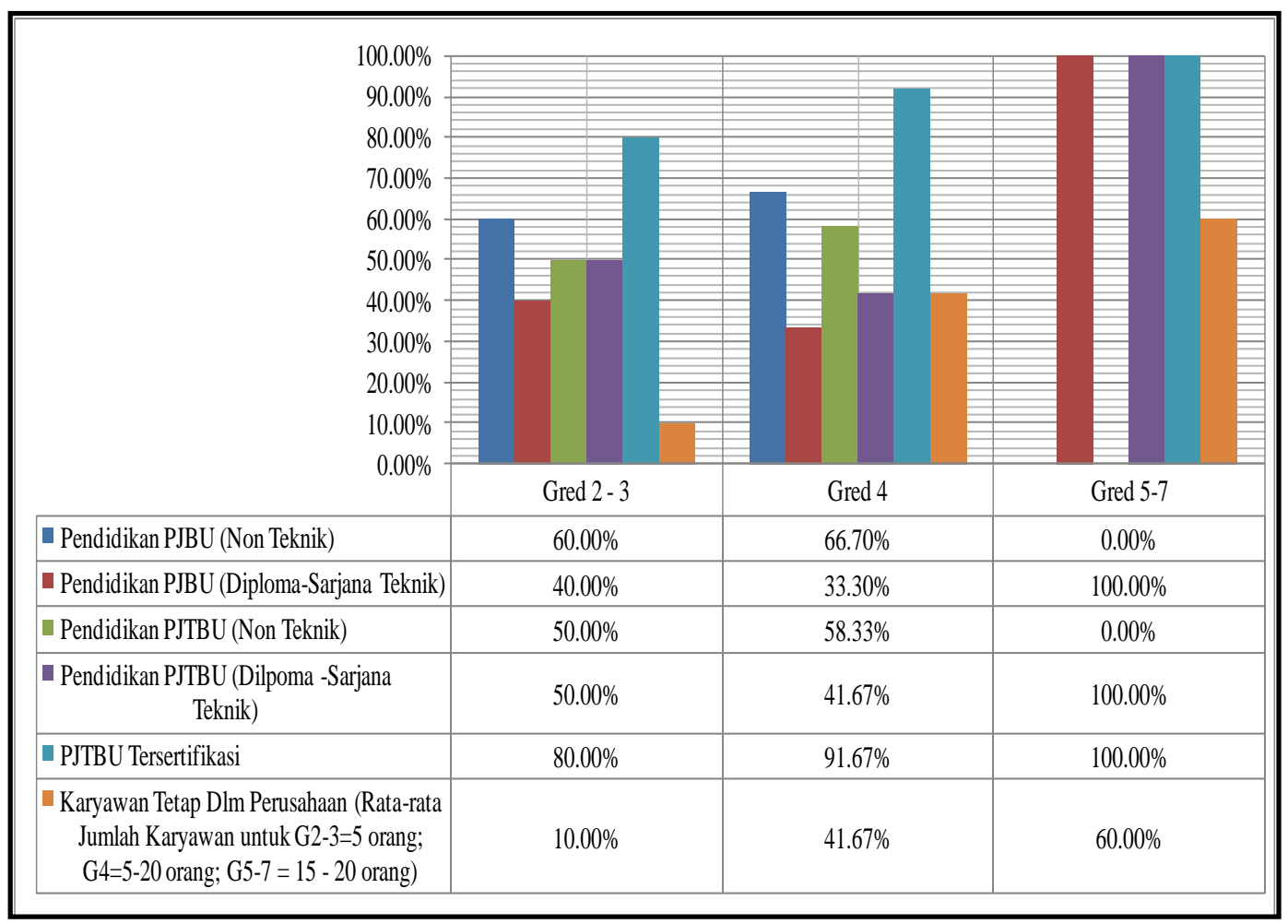


d. Karakteristik Keuangan dan Permodalan yang dimiliki oleh kontraktor lokal / kontraktor Putra Daerah di Propinsi Papua Barat.

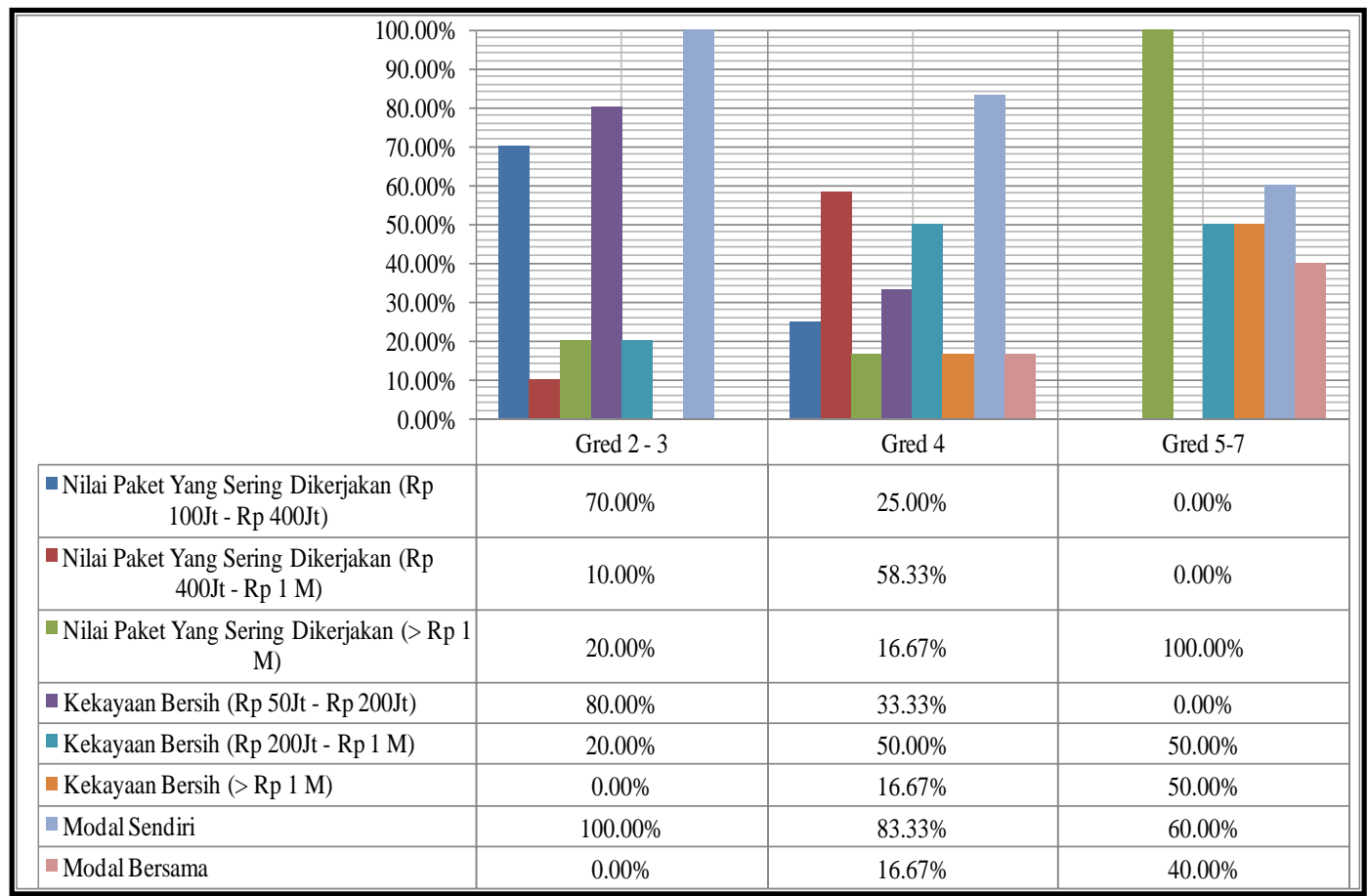

e. Karakteristik Peralatan yang dimiliki oleh kontraktor lokal / kontraktor Putra Daerah di Propinsi Papua Barat.

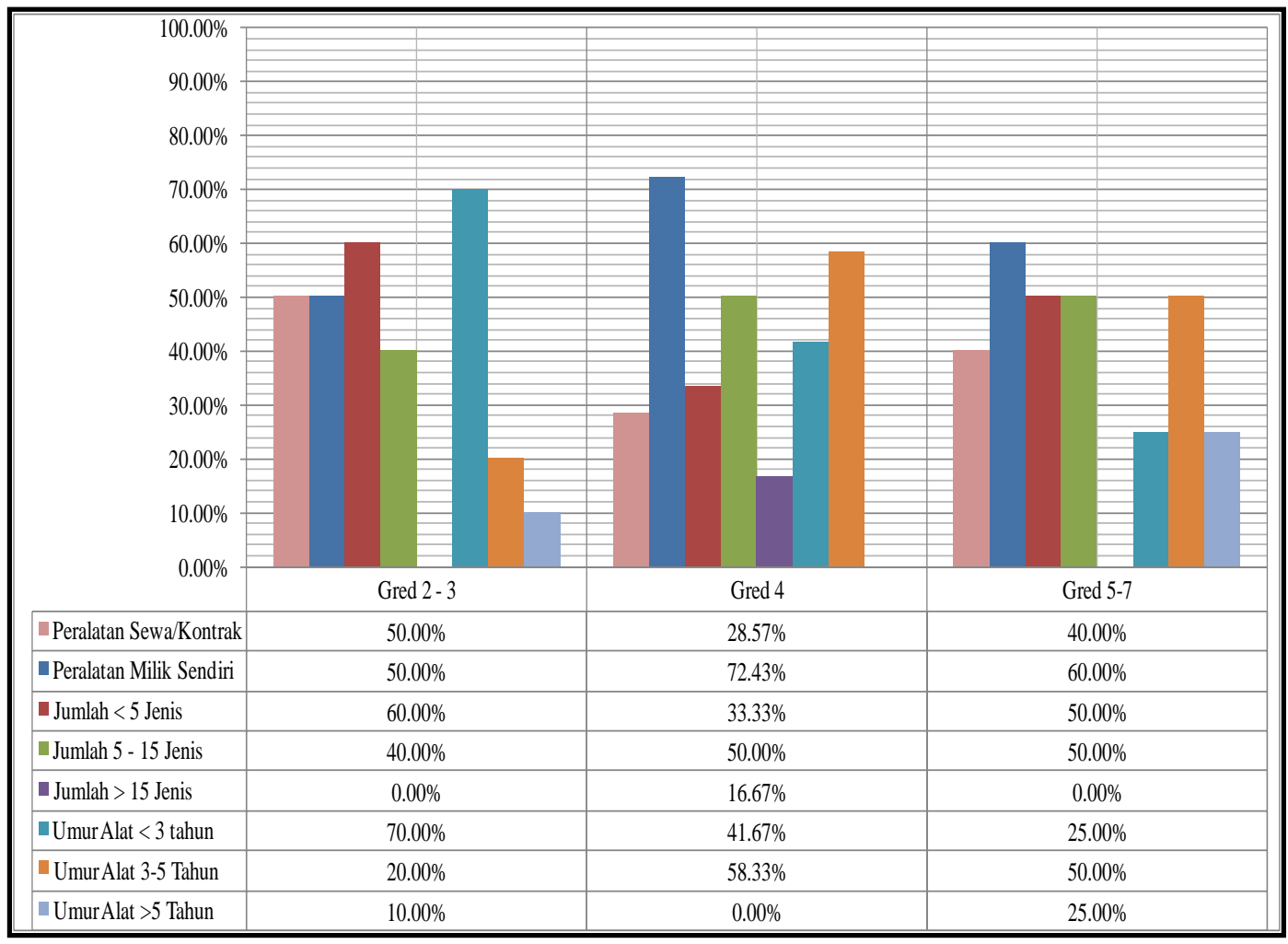


f. Karakteristik Pengalaman Kerja yang dimiliki oleh kontraktor lokal / kontraktor Putra Daerah di Propinsi Papua Barat.

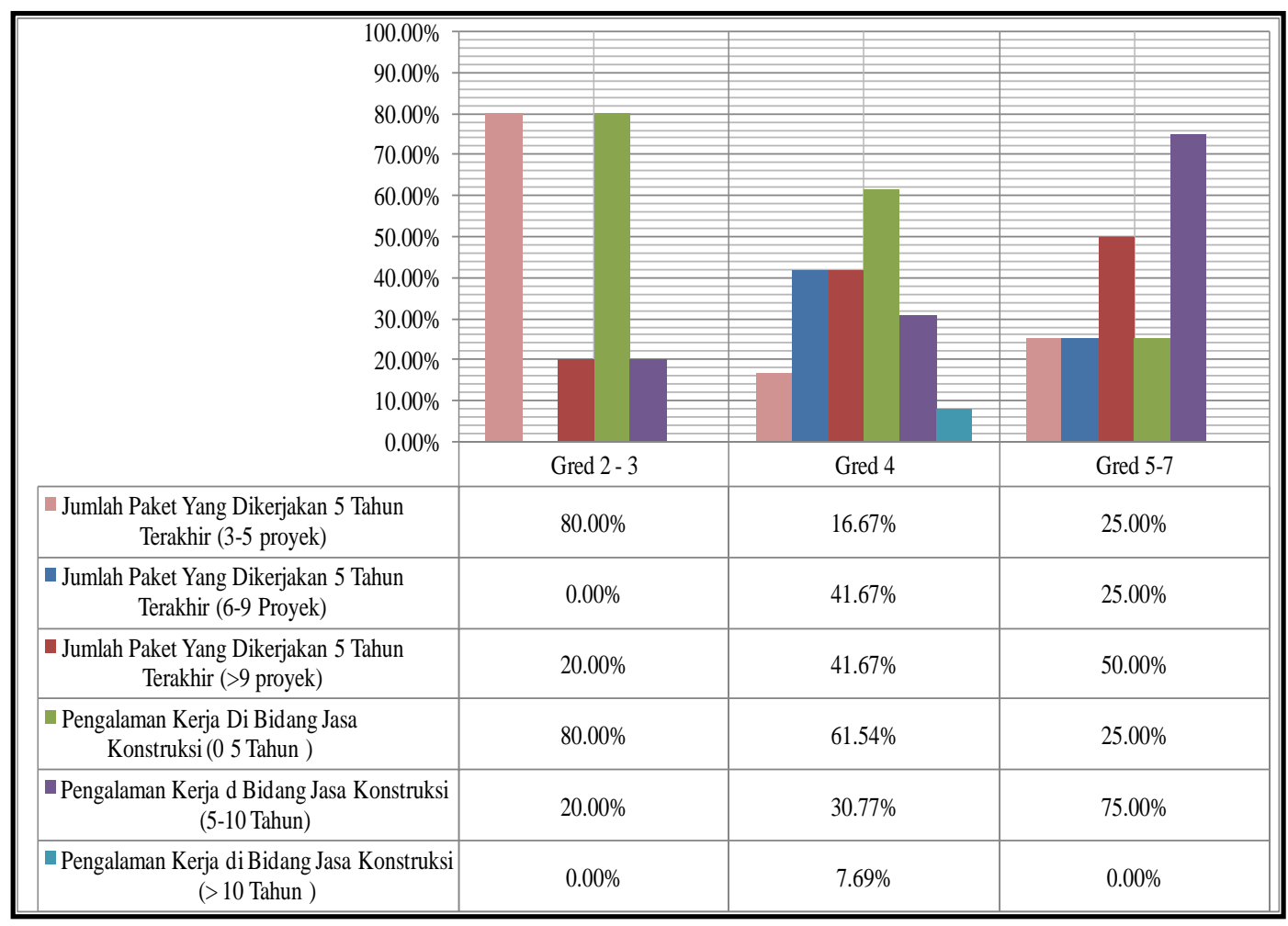

7. Gambaran persepsi kontraktor lokal/Kontraktor Putra Daerah di Propinsi Papua Barat terhadap faktor-faktor yang mempengaruhi kinerja perusahaan adalah sebagai berikut :

1. Sektor sumber daya manusia :

- Kualifikasi dan pengalaman kerja sangat penting untuk menentukan kesesuaian gaji karyawan. Di wilayah Propinsi Papua Barat teridentifikasi adanya keterbatasan SDM yang memenuhi kualifikasi sebagai tenaga teknis, hal ini terkendala mengenai latar belakang pendidikan, pengalaman kerja dan sertifikat keahlian.

- Masih perlu ditingkatkan sertifikasi dan pelatihan tenaga kerja lokal di Propinsi Papua Barat untuk meningkatkan kinerja perusahaan, khususnya bagi perusahaan/kontraktor yang dimiliki oleh pengusaha Putra Daerah Papua.

- Sehingga untuk mencapai itu semua, sistem rekruitmen dan usia tenaga kerja dianggap penting disamping masalah kualifikasi dan pengalaman kerjanya.

2. Keuangan :

- Modal perusahaan yang dipakai untuk memanajemen usaha dan melaksanakan pekerjaan dianggap faktor yang sangat penting

- Untuk mendukung permodalan khususnya bagi kontraktor lokal /pengusaha putra daerah Papua yang seringkali modalnya terbatas, 
maka perlu adanya kebijakan pemerintah maupun dunia perbankan mengenai bantuan modal khususnya untuk pengusaha lokal/ pengusaha asli Papua.

3. Peralatan dan Pengadaan Material Proyek :

- Kepemilikan peralatan secara mandiri dan termasuk merespon secara tepat pemakaian teknologi sangat dibutuhkan untuk mendukung pelaksanaan kerja.

- Kemandirian dalam proses pengadaan material yang dipakai untuk pelaksanaan pekerjaan sangat dibutuhkan untuk menunjang ketepatan waktu dan kesesuaian dengan spesifikasi. Hal ini terkait mengenai dominasi masyarakat adat di beberapa wilayah Propinsi Papua Barat terhadap penguasaan material, sehingga harga menjadi kurang terkendali atau dinamika pasar material yang kurang bisa dikendalikan oleh pemerintah setempat.

4. Metode Kerja :

- Untuk meningkatkan kinerja perusahaan, keberadaan metode kerja penting dalam pelaksanaan pekerjaan. Jalur komunikasi antara pihak perusahaan dengan pengguna jasa dan tim kerja termasuk yang perlu diperhatikan dalam hal ini, sehingga pengambilan keputusan di lapangan menjadi lebih tepat, cepat dan efisien.

5. Faktor Kepemimpinan dan Sosial Politik:

- Pentingnya untuk selalu memotivasi karyawan dan juga perlunya reward dan punishment

- Stabilitas keamanan dan kondisi politik di Propinsi Papua Barat khususnya dianggap sangat penting untuk menunjang kinerja perusahaan.

\section{Isu Strategis Dalam Perkembangan Kontraktor Lokal (Kontraktor Putra Daerah) di Propinsi Papua Barat}

8. Dari observasi terhadap responden didapatkan informasi bahwa terdapat beberapa permasalahan yang dihadapi khususnya oleh kontraktor Putra Daerah di Propinsi Papua Barat. Permasalahan-permasalahan yang dapat diinventarisasi, diberi bobot dan kemudian diurutkan sesuai dengan respon dari sampel perusahaan di Propinsi Papua Barat adalah sebagai berikut :

\begin{tabular}{|r|l|r|r|r|r|}
\hline Urutan & Hasil Inventarisasi Permasalahan & \multicolumn{3}{|c|}{ Persepsi Responden } \\
\hline & & Gred 2-3 & Gred 4 & Gred 5-7 & Rerata \\
\hline & & & & & \\
\hline 1 & Modal & $33.33 \%$ & $42.86 \%$ & $25.00 \%$ & $33.73 \%$ \\
\hline 2 & Sumber Daya Manusia & $33.33 \%$ & $14.29 \%$ & $25.00 \%$ & $24.21 \%$ \\
\hline 3 & Peralatan & $6.67 \%$ & $7.14 \%$ & $25.00 \%$ & $12.94 \%$ \\
\hline 4 & Akses Pasar & $13.33 \%$ & $14.29 \%$ & $0.00 \%$ & $9.21 \%$ \\
\hline 5 & Fenomena kehidupan politik di era OTSUS & $0.00 \%$ & $0.00 \%$ & $25.00 \%$ & $8.33 \%$ \\
\hline 6 & Harga material yang tinggi & $13.33 \%$ & $0.00 \%$ & $0.00 \%$ & $4.44 \%$ \\
\hline 7 & Pemerintah kurang memberdayakan pengusaha2 Papua & $0.00 \%$ & $7.14 \%$ & $0.00 \%$ & $2.38 \%$ \\
\hline 8 & Fenomena kehidupan sosial budaya (aturan adat) & $0.00 \%$ & $7.14 \%$ & $0.00 \%$ & $2.38 \%$ \\
\hline 9 & Belum dijalankannya amanat UU Otsus & $0.00 \%$ & $7.14 \%$ & $0.00 \%$ & $2.38 \%$ \\
\hline
\end{tabular}


9. Dan setelah dilakukan analisa dengan metode Root Cause Analysis terhadap semua permasalahan yang terinventarisasi maka dapat diidentifikasi akar dari semua masalah tersebut adalah :

a. Belum adanya SDM yang khusus mengelola administrasi keuangan. Hal ini sangat mempengaruhi kinerja perusahaan, karena berimbas pada tidak optimalnya pengelolaan keuangan, pengelolaan logistik dan peralatan dalam pelaksanaan pekerjaan / proyek yang sedang / akan ditangani oleh para responden. Kondisi ini mayoritas dialami oleh kontraktor Putra Daerah yang perusahaannya berada pada kualifikasi Gred 2.

b. Kurang kesempatan mendapatkan pekerjaan. Pengalaman kerja menjadi item penilaian yang penting dalam proses pelelangan suatu pekerjaan, sehingga apabila kesempatan pekerjaan kurang didapatkan maka daftar pengalaman kerja juga jumlahnya menjadi sedikit. Apalagi adanya persyaratan pengalaman kerja sejenis dengan pekerjaan yang sedang dilelangkan, maka ini menuntut kontraktor untuk aktif mengakses semua kesempatan kerja.

c. Jumlah ketersediaan SDM bidang Konstruksi di Papua Barat kurang/terbatas.

- Ini adalah permasalahan serius yang dihadapi oleh kawasan Indonesia bagian timur khususnya Papua dan Papua Barat. SDM di bidang konstruksi terkonsentrasi di Pulau Jawa atau mayoritas terkonsentrasi di kawasan Indonesia bagian barat.

- Tenaga kerja teknik / engineer lokal yang dipasok oleh perguruan tinggi (politeknik maupun universitas) di wilayah Papua Barat khususnya masih dirasakan kurang untuk memenuhi kebutuhan dari kontraktor-kontraktor di wilayah Propinsi Papua Barat.

- Tawaran yang diberikan kepada engineer-engineer muda dari luar Papua untuk berkarir di Papua, ternyata kurang mendapatkan respon dan kalaupun ada jumlahnya terbatas dengan tuntutan gaji yang tinggi.

d. Dalam hal penentuan harga material lokal, hukum/aturan adat lebih mendominasi daripada hukum /peraturan pemerintah daerah. Hal ini terjadi di beberapa daerah, khususnya di daerah kepulauan dan daerah pedalaman di wilayah Propinsi Papua Barat. Harga material lokal seperti pasir dan batu karang atau batu gunung kadang melebihi dari harga yang ditetapkan oleh pemerintah setempat. Dinamika pasar material kurang bisa dikendalikan oleh pemerintah setempat, sehingga kadang menyebabkan membengkaknya biaya pekerjaan melebihi estimasi biaya yang telah dibuat oleh pemilik pekerjaan. 
D. Rumusan Konsepsi Kebijakan Untuk Mengatasi Akar Masalah Yang dihadapi oleh Kontraktor Lokal/Kontraktor Putra Daerah di Propinsi Papua Barat.

10. Dengan metode Root Cause Analysis telah diidentifikasi adanya 4 (empat) akar masalah yang saat ini dihadapi oleh kontraktor Putra Daerah di Propinsi Papua Barat, yaitu 1). Belum adanya SDM yang khusus mengelola administrasi dan keuangan; 2). Kurangnya mendapat kesempatan pekerjaan; 3). Jumlah ketersediaan SDM bidang Konstruksi di Papua Barat kurang/terbatas; dan 4). Dalam hal penentuan harga material lokal, hukum/aturan adat lebih mendominasi daripada hukum /peraturan pemerintah daerah

11. Dalam rangka mendukung pembinaan dan pemberdayaan terhadap kontraktor Putra Daerah di Propinsi Papua Barat perlu disusun konsep kebijakan, sehingga bisa menjadi solusi yang tepat untuk menjawab permasalahan-permasalahan tersebut.

a. Belum adanya SDM yang khusus mengelola administrasi dan keuangan.

Konsep Kebijakan yang ditawarkan : Mendorong pola kerjasama antara kontraktor putra Papua dengan kontraktor lain baik dari sisi permodalan, SDM dan peralatan

Instansi penanggungjawab / pengelola kebijakan : Asosiasi kontraktor di bawah pembinaan LPJK Propinsi Papua Barat

b. Kurangnya mendapat kesempatan pekerjaan.

Konsep Kebijakan yang ditawarkan : Mendorong Pemerintah Daerah untuk membuat kebijakan yang mewajibkan kontraktor yang mendapatkan pekerjaan bernilai besar untuk membina kontraktor lokal dengan sistem sub kontraktor

Instansi penanggungjawab / pengelola kebijakan : Pemerintah Daerah di Lingkungan Propinsi Papua Barat

c. Jumlah ketersediaan SDM bidang Konstruksi di Papua Barat kurang/terbatas.

Konsep Kebijakan yang ditawarkan :

- Mengoptimalkan pelatihan dan pembinaan tenaga kerja lokal di bidang jasa kontruksi

- Mendorong pola kerjasama antara kontraktor putra Papua dengan kontraktor lain baik dari sisi permodalan, SDM dan peralatan

Instansi penanggungjawab / pengelola kebijakan :

- LPJK Propinsi Papua Barat.

- Asosiasi kontraktor di bawah pembinaan LPJK Propinsi Papua Barat

d. Dalam hal penentuan harga material lokal, hukum/aturan adat lebih mendominasi daripada hukum /peraturan pemerintah daerah.

Konsep Kebijakan yang ditawarkan : Mendorong pemerintah daerah untuk aktif mensosialisasikan dan menegakkan peraturan yang berlaku tentang pengelolaan dan pengaturan harga material untuk pekerjaan konstruksi 
Instansi penanggungjawab / pengelola kebijakan : Pemerintah Daerah di Lingkungan Propinsi Papua Barat

12. Secara garis besar, keempat konsepsi kebijakan di atas dapatlah dijadikan entry point dalam upaya penyusunan Model Pemberdayaan bagi Kontraktor Lokal / Pengusaha Putra Papua dalam Bidang Jasa Konstruksi. Hal ini diperlukan untuk mendukung terlaksananya amanat UU Otonomi Khusus dan Percepatan Pembangunan di Wilayah Papua. Oleh karena itu perlu dirumuskan juga program lanjutan dari penelitian ini, yaitu :

- Perlunya studi/penelitian lanjutan terkait dengan bagaimana sistem pemberdayaan yang sesuai untuk berkembangnya kontraktor lokal / pengusaha papua di propinsi papua Barat.

- Perlunya studi/penelitian lanjutan mengenai pemetaan tenaga kerja konstruksi di wilayah Propinsi Papua Barat . Hal ini diperlukan untuk mengetahui seberapa besar ketersediaan tenaga kerja berbasis pendidikan keteknikan yang bisa dipasok oleh sistem pendidikan di lokal wilayah Propinsi Papua Barat dan seberapa besar kebutuhan riil akan tenaga kerja kontruksi di wilayah Propinsi Papua Barat.

- Perlunya sistem pembinaan perusahaan lokal di bawah LPJK terintegrasi dengan sistem pembinaan dari asosiasi pengusaha yang lainnya, sehinga bisa saling melengkapi.

- Perlunya kerjasama dengan unsur perguruan tinggi di wilayah Propinsi Papua Barat khususnya dalam rangka penyiapan tenaga kerja lokal bidang keahlian teknik/konstruksi yang akan diserap oleh industri jasa konstruksi di Papua Barat. Hal ini diperlukan untuk mengurangi ketergantungan terhadap tenaga kerja dari luar daerah yang selain jumlahnya terbatas juga selama ini terkendala dengan tuntutan gaji yang tinggi.

Rumusan model kerjasama ini adalah sebagai berikut :

a. Pemerintah daerah melalui APBD membantu perguruan tinggi yang mempunyai program studi teknik sipil khususnya dalam hal pengadaan peralatan / sarana-prasarana laboratorium yang bisa dipakai untuk :

- menunjang proses pencetakan tenaga engineer yang ahli, handal dan siap kerja dengan penguasaan teori dan praktek yang berimbang.

- Menunjang pelatihan terhadap tenaga kerja lokal yang sudah dipunyai oleh industri jasa konstruksi di Propinsi Papua Barat.

Sinergi ini diperlukan, karena status perguruan tinggi di Proponsi Papua Barat yang mempunyai program studi teknik sipil adalah perguruan tinggi swasta yang masih terkendala dengan kepemilikan peralatan penunjang laboratorium sedangkan secara kualitas dan kuantitas SDM-nya sudah memenuhi. 
b. Setelah secara lokal wilayah di lingkup Propinsi Papua Barat sudah mencukupi ketersediaan tenaga kerja /engineer yang dibekali keahlian dan keterampilan kerja oleh perguruan tinggi di Propinsi Papua Barat tersebut, maka langkah selanjutnya adalah mendorong industri jasa konstruksi lokal untuk memprioritaskan pemakaian tenaga kerja lokal tersebut. Sehingga diharapkan terjadi keseimbangan antara ketersediaan tenaga kerja konstruksi dengan kebutuhan riil tenaga kerja pada industri jasa konstruksi di wilayah Propinsi Papua Barat.

13. Tahapan demi tahapan yang diuraikan diatas diharapkan akan bermuara pada grand design tentang Peningkatan Sumber Daya Manusia (SDM) bagi Kontraktor Putra Daerah di Propinsi Papua Barat. Dan apabila SDM sudah bagus dalam pengelolaan perusahaan dan dalam pelaksanaan pekerjaan di lapangan maka hal tersebut nantinya akan berbanding lurus dengan Kepercayaan Pasar Kerja dan Terbukanya Kesempatan Kerja dalam Persaingan Industri Jasa Konstruksi di Propinsi Papua Barat. Sehingga nantinya semangat dari amanat UU Otsus yaitu "Orang asli Papua berhak memperoleh kesempatan dan diutamakan untuk mendapatkan pekerjaan dalam semua bidang pekerjaan di wilayah Provinsi Papua berdasarkan pendidikan dan keahliannya" - bisa terjawab secara tuntas. 